\title{
Capital Structure and Financial Performance: Analysis of Selected Business Companies in Bombay Stock Exchange
}

\author{
Rakesh H M \\ Assistant Professor, Dept. of Business Administration Vidyavardhaka College of Engineering, Mysore \\ Karnataka, India
}

\begin{abstract}
Capital structure is most significant discipline of company's operations. This study constitutes an attempt to identify the impact between Capital Structure and Companies Performance, taking into consideration the level of Companies Financial Performance. The analysis has been made on the capital structure and its impact on Financial Performance capacity during 2009 to 2012 (03 years) financial year of Business companies in India. The results show the relationship between the capital structure and financial performance is having a negative association. It reflects the insignificant level of the Business Companies in India. Hence Business companies mostly depend on the debt capital. Therefore, they have to pay interest expenses much.
\end{abstract}

Key Words: Capital Structure, Financial Performance, Business Companies

\section{Introduction}

Modigliani and Miller published their paper on the cost of capital, corporate finance and investment theory in 1958, and hence the development of their capital structure irrelevance theorem, a vast amount of research has focused on companies' capital structure. (Modigliani \& Miller, 1958) Several theories have been developed in the attempt to arrive at one that is able to explain the financing behavior of companies as well as establishing whether an optimal capital structure exists. Theories such as agency theory (Jensen \& Meckling, 1976), tradeoff theory (Modigliani \& Miller, 1963) and pecking order theory (Myers \& Majluf, 1984; Myers, 1984), with the latter two being the most dominant, have been developed and used in the attempt to explain companies' capital structure. The trade-off theory advances that the choice of capital structure in a firm is a result of a tradeoff between the benefits of debt, such as those arising from interest debt tax shield, and the costs of debt, such as indirect and direct bankruptcy costs (Myers, 1984), whereas the pecking order theory states that companies prefer the cheapest source of funding, which due to information asymmetry, means companies prefer internal to external funding as well as debt to equity funding. (Myers \& Majluf, 1984)

Numerous studies have been carried out to empirically test capital structure theories which try to establish whether they could explain the capital structure of companies as well as figuring out which determinants were important when considering companies' capital structure. However, despite the immense amount of existing research, the ability of the theories to explain the capital structures of firm remain limited. (Graham \& Leary, 2011) The continued focus on companies' capital structure highlights the importance and relevance of this area of study as researchers continue to arrive at new possible directions and views to implement in future research.

The relationship between capital structure and financial performance is one that received considerable attention in the finance. How important is the concentration of control for the company performance or the type of investors exerting that control are questions that authors have tried to answer for long time prior studies show that capital structure has relating with corporate governance, which is the key issues of state owned enterprise. To study the effects of capital structure or financial performance, will help us to know the potential problems in performance and capital structure.

\section{Objectives}

The focus of this study is studying Impact of Capital Structure on Performance of the Business industry in listed companies in India.

1. To study the impact of capital structure on financial performance

2. To Evaluate the relationship between capital structure and performance

3. To determine the determinants of a capital structure

\author{
Hypothesis \\ The following are the hypothesis for the study; \\ $\mathrm{H}_{0}$ :-Negative relationship between capital structure and financial performance. \\ $\mathrm{H}_{1}$ :- The capital structure has significant impact on financial performance. \\ $\mathrm{H}_{2}$ :-There is positive relationship between capital structure and financial performance.
}




\section{Methodology}

The research is conducted by using the data gathered from the financial statements as published by Business Companies. In addition, another source of data was through reference to the review of different journals, papers, articles and relevant previous studies of listed companies of Bombay Stock Exchange. All firms are taken for the study representing the period of 2009-2012, and the average values of each item was considered for the purpose of ratio computation and analysis.

\section{Correlation Analysis}

\section{Results And Discussions}

The correlation co-efficient describes the relationship exist between capital structure and financial performance. The correlation co-efficient analysis is under taken to find out the relationship between capital structure and financial performance in this study

\section{Capital structure and Gross profit}

Table I

\begin{tabular}{|l|l|l|}
\hline Variables & Capital Structure & Gross Profit \\
\hline Capital Structure & 1 & 0.387 \\
\hline Gross Profit & 0.387 & 1 \\
\hline
\end{tabular}

Above table is showing the relationship between gross profit and capital structure variables. There is a weak positive relationship between two variables. The correlation is 0.387 . Significance level is 0.01 ; the co-efficient of determination is 0.1296 . That is only $12.96 \%$ of variance in the capital structure is accounted by the gross profit. It can be said that there is a weak positive relationship between capital structure and gross profit

\section{Capital structure and Net profit}

Table II

\begin{tabular}{|l|l|l|}
\hline Variables & Capital Structure & Net Profit \\
\hline Capital Structure & 1 & -0.098 \\
\hline Net Profit & -0.098 & 1 \\
\hline
\end{tabular}

It is related to the relationship between net profit and capital structure variables. There is a weak negative relationship between two variables. The correlation is -0.098 . Significance level is 0.01 . The co-efficient of determination is 0.0121 . That is only $1.21 \%$ of variance in the capital structure is accounted by the net profit.

\section{Capital structure and ROI}

\section{Table III}

\begin{tabular}{|l|l|l|}
\hline Variables & Capital Structure & ROI \\
\hline Capital Structure & 1 & -0.113 \\
\hline ROI & -0.113 & 1 \\
\hline
\end{tabular}

It is indicating the relationship between ROI and capital structure variables. There is a weak negative relationship between two variables. The correlation is -0.113 . Significance level is 0.01 . The coefficient of determination is 0.0108 that is only $1.08 \%$ of variance in the capital structure is accounted by the ROI.

\section{Capital structure and ROA}

\section{Table IV}

\begin{tabular}{|l|l|l|}
\hline Variables & Capital Structure & ROA \\
\hline Capital Structure & 1 & -0.158 \\
\hline ROA & -0.158 & 1 \\
\hline
\end{tabular}

It is showing the relationship between ROA and capital structure variables. There is a weak negative relationship between two variables. The correlation is -0.158 significant level is 0.01 . The co-efficient of determination is 0.0384 , that is only $3.84 \%$ of variance in the capital structure is accounted by the ROA. 
Capital structure and financial performance

Table V

\begin{tabular}{|l|l|l|}
\hline Variables & Capital Structure & Financial Performance \\
\hline Capital Structure & 1 & -0.109 \\
\hline Financial Performance & -0.109 & 1 \\
\hline
\end{tabular}

It shows the relationship between performance and capital structure variables. There is a weak negative relationship between two variables. The correlation is -0.109 . Significance level is 0.01 . The co-efficient of determination is 0.0129 that is only $1.29 \%$ of variance in the capital structure is accounted by the performance.

\section{Regression Analysis}

It is used to test the impact of financial performance on capital structure of the listed companies traded in Bombay stock exchange

\section{Capital structure and Gross profit}

Table VI

\begin{tabular}{|l|l|l|l|l|}
\hline Model & R & R Square & $\begin{array}{l}\text { Adjusted R } \\
\text { Square }\end{array}$ & $\begin{array}{l}\text { Std Error of the } \\
\text { estimate }\end{array}$ \\
\hline 1 & 0.387 & 0.149 & 0.096 & 0.3127 \\
\hline
\end{tabular}

The above table shows the weak positive correlation between the capital structure and gross profit.

Table VII

\begin{tabular}{|l|l|l|l|l|l|l|l|}
\hline \multirow{2}{*}{ Model } & \multicolumn{2}{|l|}{$\begin{array}{l}\text { Un-standardized Co- } \\
\text { efficient }\end{array}$} & $\begin{array}{l}\text { Standardized Co- } \\
\text { efficient }\end{array}$ & \multicolumn{2}{l|}{ Sig } \\
\cline { 2 - 7 } & $\mathrm{B}$ & Standard Error & Beta & & \\
\hline Constant & 0.184 & 0.07 & & 2.552 & 0.016 \\
\hline Capital Structure & 0.043 & 0.026 & 0.387 & 2.036 & 0.051 \\
\hline
\end{tabular}

The above table indicates the coefficient of correlation between the capital structure and gross profit. Multiple $\mathrm{r} 2$ is 0.149 only $1.49 \%$ of variance of gross profit is accurate by the capital structure. But, remaining $98.51 \%$ of variance with gross profit is attributed to other factors.

\section{Capital structure and Net profit}

Table VIII

\begin{tabular}{|l|l|l|l|l|l|}
\hline Model & R & R Square & $\begin{array}{l}\text { Adjusted } \\
\text { Square }\end{array}$ & $\begin{array}{l}\text { Std Error of the } \\
\text { estimate }\end{array}$ \\
\hline 1 & 0.098 & 0.0096 & -0.026 & 0.3521 \\
\hline
\end{tabular}

The above table shows the weak negative correlation between the capital structure and net profit.

Table IX

\begin{tabular}{|l|l|l|l|l|l|}
\hline \multirow{2}{*}{ Model } & \multicolumn{2}{|l|}{ Co- } & \multirow{2}{*}{ Standardized } & \multirow{2}{*}{ Sig } \\
\cline { 2 - 5 } & Un-standardized Co-efficient & Beta & & \\
\hline Constant & 0.126 & 0.085 & & 1.486 & 0.145 \\
\hline Capital Structure & -0.018 & 0.023 & -0.098 & -0.579 & 0.564 \\
\hline
\end{tabular}

The above table indicates the coefficient of correlation between the capital structure and net profit. Multiple r2 is 0.0096 . Only $0.96 \%$ of variance of net profit is accurate by the capital structure. But, remaining $99.04 \%$ of variance with net profit is attributed to other factors

\section{Capital structure and ROI}

Table X

\begin{tabular}{|l|l|l|l|l|}
\hline Model & $\mathbf{R}$ & $\begin{array}{l}\text { R } \\
\text { Square }\end{array}$ & $\begin{array}{l}\text { Adjusted } \\
\text { Square }\end{array}$ & $\begin{array}{l}\text { Std Error of the } \\
\text { estimate }\end{array}$ \\
\hline 1 & 0.113 & 0.0127 & -0.023 & 114.1329 \\
\hline
\end{tabular}

The above table shows the weak positive correlation between the capital structure and ROI. 
Table XI

\begin{tabular}{|l|l|l|l|l|l|}
\hline \multirow{2}{*}{ Model } & \multicolumn{2}{|l|}{ Co- } & \multirow{2}{*}{ T } & \multirow{2}{*}{$\begin{array}{l}\text { Standardized } \\
\text { efficient }\end{array}$} \\
\cline { 2 - 5 } & Bn-standardized Co-efficient & Beta & & \\
\hline Constant & 31.458 & 26.060 & & 1.205 & 0.240 \\
\hline Capital Structure & -4.583 & 8.246 & -0.113 & -0.556 & 0.585 \\
\hline
\end{tabular}

The above table indicates the coefficient of correlation between the capital structure and ROI.

Multiple $\mathrm{r} 2$ is 0.0127 . Only $1.27 \%$ of variance of ROI is accurate by the capital structure. But, remaining $98.73 \%$ of variance with $\mathrm{ROI}$ is attributed to other factors

\section{Capital structure and ROA}

Table XII

\begin{tabular}{|l|l|l|l|l|}
\hline Model & R & $\begin{array}{l}\text { R } \\
\text { Square }\end{array}$ & $\begin{array}{l}\text { Adjusted } \\
\text { Square }\end{array}$ & $\begin{array}{l}\text { Std Error of the } \\
\text { estimate }\end{array}$ \\
\hline 1 & 0.158 & 0.0249 & 0.002 & 0.1096 \\
\hline
\end{tabular}

The above table shows the weak positive correlation between the capital structure and ROA.

Table XIII

\begin{tabular}{|c|c|c|c|c|c|}
\hline \multirow[t]{2}{*}{ Model } & \multicolumn{2}{|c|}{ Un-standardized Co-efficient } & $\begin{array}{l}\text { Standardized Co- } \\
\text { efficient }\end{array}$ & \multirow[t]{2}{*}{$\mathrm{t}$} & \multirow[t]{2}{*}{ Sig } \\
\hline & $\mathrm{B}$ & Standard Error & Beta & & \\
\hline Constant & 0.097 & 0.025 & & 4.022 & 0 \\
\hline Capital Structure & -0.006 & 0.008 & -0.158 & -1.058 & 0.298 \\
\hline
\end{tabular}

The above table indicates the coefficient of correlation between the capital structure and ROA. Multiple r2 is 0.0249 , only $2.49 \%$ of variance of ROA is accurate by the capital structure. But, remaining $97.51 \%$ of variance with ROA is attributed to other factors

\section{Capital structure and financial performance}

Table XIV

\begin{tabular}{|l|l|l|l|l|}
\hline Model & R & $\begin{array}{l}\text { R } \\
\text { Square }\end{array}$ & $\begin{array}{l}\text { Adjusted } \\
\text { Square }\end{array}$ & $\begin{array}{l}\text { Std Error of the } \\
\text { estimate }\end{array}$ \\
\hline 1 & 0.109 & 0.0118 & -0.022 & 0.97385 \\
\hline
\end{tabular}

The above table shows the weak positive correlation between the capital structure and performance.

Table XV

\begin{tabular}{|c|c|c|c|c|c|}
\hline \multirow[t]{2}{*}{ Model } & \multicolumn{2}{|c|}{ Un-standardized Co-efficient } & $\begin{array}{l}\text { Standardized Co- } \\
\text { efficient }\end{array}$ & \multirow[t]{2}{*}{$\mathrm{t}$} & \multirow[t]{2}{*}{ Sig } \\
\hline & $\mathrm{B}$ & Standard Error & Beta & & \\
\hline Constant & 0.702 & 0.225 & & 3.158 & 0.004 \\
\hline Capital Structure & -0.041 & 0.068 & -0.109 & -0.602 & 0.550 \\
\hline
\end{tabular}

The above table indicates the coefficient of correlation between the capital structure and performance. Multiple $\mathrm{r} 2$ is 0.0118 only $1.18 \%$ of variance of performance is accurate by the capital structure. But, remaining $98.82 \%$ of variance with performance is attributed to other factors.

Table XVI

\begin{tabular}{|l|l|l|l|l|l|}
\hline Model & $\begin{array}{l}\text { Sum of } \\
\text { Squares }\end{array}$ & df & $\begin{array}{l}\text { Mean } \\
\text { Square }\end{array}$ & F & Sig. \\
\hline Regression & 0.208 & 1 & 0.208 & 0.22 & 0.550 \\
\hline Residual & 27.114 & 28 & 0.969 & & \\
\hline Total & 27.322 & 29 & & & \\
\hline
\end{tabular}

An examination with ANOVA (F-value) indicates that explains the most possible combination of predictor variables that could contribute to the relationship with the dependent variables. For model $1-\mathrm{F}$ value is 0.22 we see that all of the corresponding F Value is insignificant in respect to their consequent values. However, it should be noted here that there may be some other variables which can have an impact on financial performance, which need to be studied. 


\section{Conclusion}

Correlation analysis explains, there is a weak positive relationship between gross profit and capital structure (0.387). At the same time, there is a negative relationship between net profit and capital structure (0.098), it reflects the high financial cost among the firms. ROI and ROA also has negative relationship with capital structure at $-0.113,-0.158$ respectively.

It is focused on the overall point of view of the relationship between the capital structure and financial performance. There is a negative association at -0.109 . F value is 0.22 . It reflects the insignificant level of the Business Companies in India. Business companies mostly depend on the debt capital. Therefore, they have to pay interest expenses much.

\section{Testing of Hypotheses}

Statistical Techniques Results

H1 hypothesis is false because in this study the empirical results shows that there is a insignificant negative relationship

H2: "There is a positive relationship between the capital structure and firm's financial performance".

Hypothesis (H1) was considered and tested for its validity. It has the following result between the capital structure and firm's financial performance measured by performance measures such as ROA, ROI, Net profit margin and etc. Based on the above evidence gathered, the $\mathrm{H} 2$ was rejected because research result is negative relationship between the capital structure and firm's financial performance.

H0: "there is a negative relationship between the capital structure and firm's financial performance".

After the rejection of $\mathrm{H} 1$, the Null hypothesis (H0) was tested for its validity. $\mathrm{H} 0$ was accepted based on the above evidence gathered that it has been providing evidence that there is a negative relationship between the capital structure and firm's financial performance.

\section{Suggestions and Recommendations}

The following suggestions are recommended to increase the Company's financial performance based on capital structure.

1. Establishing the Performance standards and communicating to the investors. It will help investor in taking standard and better investment decisions.

2. Identification of investment weaknesses may result in improving the firm's financial performance, as it indicates the area for decision making.

3. Motivating the investors will help to achieve firm's financial performance.

4. Political changes influence the share market. It will also determine the firm performance. Therefore, it should favorable and possible to increase the financial performance of the listed companies.

5. Inflation and exchange rate will reflect the listed company's performance. The government should consider the economic growth to control the inflation.

\section{References}

[1]. Fama, E., 1986. Premiums and default premiums in money markets. Journal of Financial Economics 17, 175-196

[2]. Guo, X., Miao, J., Morellec, E., 2005. Irreversible investment with regime shifts. Journal of Economic Theory 122, 37-59.

[3]. Korajczyk, R., Levy, A., 2003. Capital structure choice: Macroeconomic conditions and financial constraints. Journal of Financial Economics 68, 75-109.

[4]. Lambrecht, B., 2001. The impact of debt financing on entry and exit. Review of Financial Studies 14, 765-804.

[5]. Leland, H., 1994. Corporate debt value bond covenants and optimal capital structure.

[6]. Mello, A., Parsons, J., 1992. Measuring the agency cost of debt. Journal of Finance 47, 1887-1904.

[7]. Merton, 1974. On the pricing of corporate debt: the risk structure of interest rates. Journal of Finance 29, 449-470.

[8]. Miao, J., 2005. Optimal capital structure and industry dynamics. Journal of Finance 60, 2621-2659.

[9]. Modigliani, F., Miller, M., 1958. The cost of capital, corporation finance, and the theory of investment. American Economic Review 48, 261-297.

[10]. Morellec, E., 2004. Can managerial discretion explain observed leverage ratios? Review of Financial Studies 17, 257-294.

[11]. Morellec, E., 2001. Asset liquidity, capital structure and secured debt. Journal of Financial Economics 61, $173-206$.

[12]. Fan, H., Sundaresan, S., 2000. Debt valuation, renegotiation, and optimal dividend policy. Review of Financial Studies 13, 10571099. 